Сања М. Куљанин ${ }^{*}$

https://doi.org/10.18485/ai_zsjoski.2018.1.21

Универзитет у Источном Сарајеву

821.163.41.09 Андрић И.

Филозофски факултет Пале

Катедра за србистику

\title{
КОНКУРЕНТНОСТ СИНТЕТИЧКЕ И АНАЛИТИЧКЕ КОМПАРАЦИЈЕ У АНДРИЋЕВОМ ДЈЕЛУ
}

Синтетичка и аналитичка компарација битно се разликују у аспекту који се тиче узлазности и силазности. За узлазну примарна је синтетичка, а за силазну аналитичка компарација. Међутим, празна мјеста унутар компаративног семантичког аспекта морају се попуњавати на различите начине. Реферат има за циљ интерференцију двају типова поредбеног поступка, који подразумијева или стилску или комуникативну варијанту.

Кључне ријечи: компарација, синтетичка, аналитичка, узлазна, силазна, експресивност.

\section{Увод}

Иво Андрић, као писац који је стварао у Србији и писао на српском језику, који је својим књижевним стваралаштвом дао огроман допринос српској књижевности и српском језику, увијек је актуелан и инспиративан, а његово умјетничко дјело, језик и стил препознатљиви су, те језичким посленицима омогућавају бескрајне и разноврсне лингвистичке анализе на свим језичким нивоима.

* sanja.kuljanin@ffuis.edu.ba 
У овоме раду биће издвојене и анализиране компарационе конструкције, и синтетичке и аналитичке, указаће се на њихову конкурентност и на интерференцију двају типова поредбеног поступка, који подразумијева или стилску или комуникативну варијанту.

Општепознато је да је компарација граматичка категорија својствена квалитативним придјевима и прилозима хомоформним с придјевима средњег рода, под којом се подразумијева могућност степеновања особине, својства или уопште неке квалификације изражене придјевом или прилогом. У вези с тим, у свим србистичким/сербокроатистичким граматикама наводи се трочлана компарациона парадигма (позитив, компаратив $и$ суперлатив) и начини творбе компаративних и суперлативних облика.

На основу увида у писање о компарацији придјева/ прилога, може се рећи да се у школским граматикама обрађује само компарација синтетичког типа, мада се тај термин не помиње. А ријетко се помиње и чињеница да у нашем језику компарација може, а у неким случајевима и мора бити исказана на лексичком плану, аналитичким/ перифрастичким конструкцијама. У научној литератури први детаљнији радови о овим конструкцијама припадају М. Ковачевићу (2003), који је, на богатом језичком материјалу из различитих функционалних стилова српског стандардног језика, указао на разноврсне могућности аналитичког изражавања компаративних и суперлативних значења, те издвојио и описао узуалне моделе перифрастичког компаратива и перифрастичког суперлатива, као нужне граматичке форме.

Основни компарациони аналитички или перифрастички модел јесте двочлана синтагма чији је надређени члан квалификативна придјевска/прилошка лексема, а подређени лексема која својим квантитативним семантичким компонентама у позицији испред придјева/при- 
лога управо и омогућава овакав начин исказивања већег или мањег степена заступљености дате квалификације. Да би испунила наведену функцију, та се квантитативна лексема мора употријебити с одређеним морфолошким обиљежјем, које је индикатор степена заступљености дате особине. Да би се исказало перифрастичко узлазно компаративно значење, испред надређеног придјева/ прилога употребљава се компаративна лексема вище, а за силазну градацију лексема мање. Суперлативно значење захтијева исте лексеме али у облику суперлатива, за климактичку градацију лексему највище, а за антиклимактичку мора се употријебити лексема најмане. Према томе, општи модел за исказивање лексичко-граматичке, описне форме узлазног и силазног компаратива и суперлатива гласи: више/мане; највише/најмане + позитив придјева/прилога.

Употреба лексичко-граматичких, аналитичких форми нужна је, прије свега, у случају компарације индеклинабилних придјева. Ријеч је о придјевима страног поријекла, којих је у посљедње вријеме све више у нашем језику (кич, мане/више кич, најмане/највише кич, тако и: кул, ин, aym, фенси, фит и сл.), али такве примјере нисмо забиљежили у нашем корпусу ${ }^{2}$. И синтаксичка конструкција може наметнути употребу перифрастичког облика, па се тако у поредбеним конструкцијама с ријечју него која повезује компаратив с позитивом придјева или прилога, у позицији компаратива може употријебити само перифрастички облик, као нпр.: Има нечег више пријатног него болног у одлагању тога дана (Омерпаша, 145/146); Само му је на том коњу орма била сељачка, вище пртена него кожна (Јелена, 48) (Ковачевић 2003: 19).

2 Пуни библиографски подаци за Андрићева књижевна дјела из којих су ексцерпирани примјери дати су у списку извора на крају овога рада. 
Наведени типови аналитичке компарације искључују употребу синтетичке форме, па је у таквом случају ријеч о комплементарној дистрибуцији у контекстима међусобне супституентности. Међутим, облици описне, перифрастичке компарације могу бити и у конкурентском односу са синтетичким, ако у датом контексту постоји могућност њихове међусобне супституције, на који ћемо и указати у овоме раду. А у директној вези с тим је и још једна карактеристика компарације, а то је могућност исказивања садржаја придјева или прилога у већој или мањој мјери у односу на позитив, па у вези с тим критеријумом компарација може бити узлазна/климактичка и силазна/антиклимактичка. Управо у том аспекту, који се тиче узлазности и силазности, синтетичка и аналитичка компарација битно се разликују. За узлазну примарна је синтетичка, а за силазну аналитичка компарација, а граматичка норма налаже употребу синтетичког компаратива и суперлатива кад год је то могуће. Треба нагласити да позитив, компаратив и суперлатив чине компарациону парадигму само уколико се односе на исту лексему, тј. ако је испоштован граматичко-системски аспект хомолексичности чланова компарацијске парадигме, што значи да се према позитиву равнају и остали облици, и узлазни и силазни компаратив и суперлатив.

\section{Климактичка аналитичка компарација}

Представићемо прво примјере узлазног аналитичког компаратива и суперлатива који се остварују према наведеном основном моделу и анализирати дистрибуцију аналитичких облика, разматрајући њихов суоднос са синтетичким формама. Како је већ истакнуто, узлазна компарација првенствено је синтетичка, те сходно томе није ни забиљежен велики број примјера овог типа аналитичке компарације у анализираном корпусу. Навешћемо 
неке од њих како бисмо уочили разлоге употребе тих перифрастичких конструкција:

(1) Легла је и угасила светлост, али се у мраку нашла још

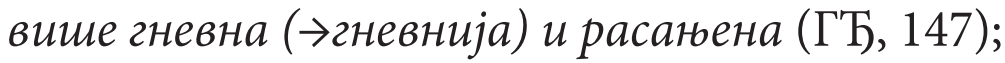

Иако је еквивалентни граматички, синтетички компаратив гневнија, забиљежен и у Правопису српског језика (2010: 289) сасвим уобичајен, Андрић се опредјељује за перифрастички, који је, дакле, у конкурентском односу са синтетичким. Узрок употребе перифрастичке форме компаратива, како се наводи у литератури, „може бити или непознавање граматичке норме српскога језика или пак свјесно нарушавње тих правила из стилистичких разлога" (Ковачевић 2003: 22). А облици перифрастичке компарације најчешће се и употребљавају управо из стилистичких, синтаксичких, па и интонационих разлога. У Андрићевом примјеру разлог за употребу аналитичке форме може бити и мања фреквентност и неуобичајеност синтетичког облика наведеног придјева, али је вјероватније да је ријеч о стилистичкој вриједности, јер се конструкцијом с лексемом више јаче изражава садржај квалификације, него наставком -ији у синтетичком компаративу гневнији, а додатно се наглашава и партикулом још, будући да је њена основна функција градациона интензификација.

Слично је и у сљедећем примјеру. То је реченица коју Андрић ставља у заграду као једну општу констатацију, унутар одломка у којем говори како га мисао о Јеленином писму недјељама није напуштала ни дању ни ноћу, нарочито преко љета, те слиједи:

(2) Јер, лето је годишње доба кад је човек највище подложан произвољној игри живаца и кад се погрешна мисао најлакше усели у нас и необичном снагом устали на једном одређеном предмету (Јелена, 275). 
За синтетички еквивалент најподложнији могло би се рећи да је због вишесложности интонационо мање погодан или непогоднији од аналитичког суперлатива, међутим, није неуобичајен, али је опет стилистички погоднији јер се суперлативом највише уз позитив придјева интензивније наглашава сама суперлативност особине или својства него суперлативном ријечцом нај- у оквиру синтетичког суперлатива. Осим тога, употребом аналитичке конструкције остварује се паралелизам суперлативних лексема, највише (подложан) и најлакще (усели), чиме је постигнута структурна компатибилност и хармоничност реченице. Али је зато суперлатив најбезбрижније у сљедећем примјеру:

(3) Сад кад је био три стотине корака далеко од њих и ваљао се према њима, мрк и тежак, као да их нагло освијести тај размак; и најбезбрижније ( $\rightarrow$ највище безбрижне) међу њима испуни страх (Јелена, 122-123),

иако вишесложан, сасвим обичан у свом синтетичком облику, док је аналитички (највище безбрижне) неуобичајен и нормативно непрепоручљив.

Исти је случај и са примјером:

(4) Даљи и недостижнији ( $\rightarrow$ више недостижан) од највећег блага и најсмелијег светског рекорда, сан је лежао негде у даљини, океан сна, а ја сам гинуо за једном једином капи његовом (Јелена, 254).

У посљедња два примјера ријеч је о синтетичком суперлативу и компаративу негираних придјева, а аналитички еквивалент, накнадно дат у загради, показује да и негиране лексеме могу градити, према основном моделу, перифрастички компаратив и суперлатив, (а у оба случаја је испоштована хомолексичност компарацијске парадигме), али су у загради наведени аналитички узлазни 
Конкурентност синтетичке и аналитичке компарације... 423

негирани компаратив и суперлатив у неравноправном односу са синтетичким формама, тј. неупоредиво су чешћи у употреби негирани морфолошки, синтетички компарациони облици. Из тога проистиче „да је примарни начин исказивања узлазне компарације у српском књижевном језику - синтетичка форма компаратива и суперлатива, без обзира на то да ли се ради о компарацији потврдних или одричних придјевских и прилошких лексема" (Ковачевић 2003: 53), што је потврђено и у Андрићевом књижевном дјелу, наравно уз истицање стилистичке вриједност примјера гдје се одступа од наведеног, јер се жели нагласити, интензификовати одређена квалификација са аспекта говорног лица.

\section{Антиклимактичка аналитичка компарација}

Силазна компарација заступљена је у већем броју примјера будући да се, како је већ речено, она примарно и изражава аналитички. Силазним (антиклимактичким) облицима компарације изражава се мањи степен заступљености особине или својства од норме коју подразумијева позитив датог придјева или прилога. Основни граматикализовани модел за аналитички компаратив гласи: мане + позитив придјева/прилога, а за аналитички суперлатив прилошка квантитативна лексема испред позитива придјева (прилога) у облику је суперлатива: најмане + позитив. Перифрастички или аналитички аспект компарације посебно је значајан за антиклимактичку градацију, јер се хомолексичност чланова компарационе парадигме, тј. правило о усаглашености компаратива и суперлатива са позитивом према истинитосној вриједности (потврдности/одричности) у случајевима силазне градације, како је већ речено, поштује само онда када се компаратив и суперлатив изражавају перифра- 
стичким формама, будући да се на граматичко-системском плану силазна компарација и веже за аналитички тип творбе. Примјери аналитичког компаратива ексцерпирани из Андрићевог књижевног дјела потврђују да је силазна градација једно од репрезентативних подручја примјене овог вида компарације. То презентују примјери које смо издвојили:

(5) Живан се склонио у сенку; и кад се јави, његов глас је сада мағе јасан (Ж, 186); Оно што је још стигао да исприча било је мане јасно, али живље (Ж, 115); Остајала је постеља, која као гроб покрива заборавом и лечи сваку муку, иако мағе савршено (Јелена, 254); Људи су бјежали у пустињу гдје је смрт била мање-више сигурна, али ипак мане страшна од Хафизових копљаника или њиховог луча и катрана (Ж, 113); Треба да се деси овакво нешто као што се јуче десило, или можда и неки мане крупан догађај, па да се разголити све што се крије у овим људима $(Г Ђ, 85) ;$ Што је њена ношња била више заостала и убога и њено држање мане женствено и привлачно, то су све више расле симпатије лепих и дотераних другарица према њој (ГЋ, 27); А и кад је дебели Анадолац неочекивано умро, од црног пришта, нови џелат, истина много мағе вешт, наставио је његов посао (НДЋ, 87); Али невјеста је бивала све оштрија и све мағе приступачна (Јелена/ММ, 167); После њега ће (...) бити лакше похватати или растерати остале, ситније и мағе веште и искусне хајдуке (Ж, 180).

У свим примјерима силазне компарације успостављена је сагласност чланова трочлане компарацијске парадигме, а силазни компаративи исказују се перифрастичким формама, чиме се и у Андрићевом дјелу потврђује значај и неопходност таквог вида компарације.

Међутим, постоје случајеви, на прагматичком плану, када се нарушава хомолексичност компаративне парадигме и тада не важи правило о усаглашености парадигме 
према истинитосној вриједности компаративног члана, тј. јавља се асиметричност у погледу чланова узлазне и силазне парадигме, прецизније речено, између позитива, с једне, и силазног компаратива и суперлатива, с друге стране. Наиме, за исказивање нижег степена заступљености одређене потврдне квалификације у синтетичкој форми (а како смо већ навели, норма препоручује синтетичку компарацију кад год је то могуће) употребљавају се негирани компаратив и суперлатив, који, како ћемо видјети, на прагматичком плану заиста „обиљежавају и умањење потврдне позитивом исказане особине” (Ковачевић 2003: 72). За потврду навешћемо сљедеће реченице из корпуса (прагматичку интерпретацију значења компаратива и суперлатива негираних лексема навешћемо у загради):

(6) Даљи и недостижнији (= мане достижан) од највећег блага и најсмелијег светског рекорда, сан је лежао негде у даљини, океан сна, а ја сам гинуо за једном једином капи његовом (Јелена, 254); Учинио сам оно што је најгоре (= најмане добро) и најнеразумније (= најмане разумно) (Јелена, 265).

Са морфолошко-системског аспекта облици синтетичког компаратива и суперлатива (недостижнији, најгоре, најнеразумније) представљају узлазну градацију негиране лексеме недостижан, лош, неразуман јер је успостављена хомолексичност компаративне парадигме. Наведени компаративни и суперлативни облици одмјеравају степен особине према негираном позитиву. Наиме, њима се исказује виши степен заступљености садржаја придјева недостижан, лош, неразуман . Међутим, исти облик, нпр. недостижнији, осим што изражава виши степен заступљености садржаја придјева недостижан, на 
прагматичком плануз може имати значење силазне компарације, али не према негираној, него према потврдној форми позитива, што показују значења перифрастичких форми у загради недостижнији (= мағе достижан), најнеразумније (= најмане разумно). На прагматичком плану могући су и обрнути примјери, да потврдни синтетички компаратив и суперлатив могу имати значење силазне градације али према негираној форми позитива, као нпр. синтетички компаратив подношльвији = мане неподношљив у сљедећој Андрићевој реченици:

(7) То је једна од оних неодређених људских жеља-нада које нас прате годинама и које се не остварују никад, само чине живот подноштивијим/= мане неподноштивим/... (Јелена, 274).

Еквивалентност ових форми можемо потврдити и тиме што компаратив подношљивији припада апсолутној компарацији, а познато је да се апсолутни компаратив приближава степену својства обиљеженог позитивом, али не достиже тај степен, тако да подноштьвији није виши степен позитива подношљив, он се у ствари налази у градационом низу између два антонима: неподношљив и подношљив и његова се семантика управо подудара с аналитичким силазним компаративом негиране лексеме манье неподношљив.

Опредијељеност за одређену језичку конструкцију, перифрастичку - при чему важи правило о усаглашено-

3 „Граматика дефинише облике, функције и правила; прагматика разматра како стварна говорна ситуација/скуп елемената као што су контекст, знање о свету, намера, когнитивно-инференцијални услови, утичу на њихов избор и значење. Прагматички ефекти употребе граматичких категорија посебно долази до изражаја у случајевима у којима систем пружа могућност избора између алтернативних облика и конструкција" (Рајић 2016: 119). 
сти парадигме према истинитосној вриједности (потврдности/одричности), или синтетичку - и преферирање таквих облика кад год је то могуће али уз нарушавање хомолексичности компаративне парадигме, у складу је с интенцијама и ставовима говорног лица, тј. с прагматичким аспектом, а тиме и са стилистичким, али и са нормативним и граматичким разлозима. Па тако, да наведемо само посљедњи примјер, Андрић се опредјељује за облик подноштивији, који је као синтетички и нормативно прихватљивиији, а не за аналитички еквивалент мане неподношъив, јер аутор и не жели живот оквалификовати лексемом неподноштив. И међу примјерима силазне аналитичке компарације (5) има и оних који су се могли исказати синтетичким формама, као нпр. мағе приступачна = неприступачнија; мане веште и искусне хајдуке = невјештије и неискусније, међутим, Андрић не жели употријебити негативну квалификацију, па у овом случају изабрана форма има и еуфемистичку улогу.

Издвојићемо још једну реченицу из корпуса у којој је заступљена аналитичка и узлазна и силазна компарација, чијом се комбинацијом постиже стилска, а не само комуникативна вриједност:

(8) Што даље одмичу и што вище дивљи (= дивљији) и мағье обични (= необичнији) и познати (= непознатији ${ }^{*}$ бивају предели кроз које пролазе, то вище бива нема $\left(=\right.$ немија $\left.{ }^{\star}\right)$ потиштеност хапшеника (Омерпаша, 67).

У наведеном примјеру предност има перифрастички компаратив из стилистичких разлога, јер је цијела сложена реченица грађена на вишеструком синтаксичком паралелизму (Ковачевић 2003: 23). Овдје су четири адјектива наведена у облику перифрастичког компаратива, два обиљежавају узлазну, више дивљи, више нијема, и два силазну компарацију, мане обични и познати. Придјев 
дивљи могао би без тешкоћа имати синтетички компаратив, иако се и употреба перифрастичког компаратива с нормативнограматичких позиција може оправдати необичношћу. Придјев нијем у свом основном значењу не може ни имати облике компарације, осим кад је фигуративно употријебљен, што овдје и јесте случај, па је перифрастички компаратив овдје сасвим прихватљив, поготово што је аналитичка форма компаратива разбијена глаголом бива. Када је ријеч о силазној градацији сљедећа два придјева, они се својим перифрастичким компаративом уклапају у структурну компатибилност реченице, иако су могући и њихови синтетички облици али, како смо раније видјели, само у специфичним граматичко-семантичким условима - у форми негираног придјева (необичнији, непознатији). Тако су придјеви у овој реченици својим облицима доведени у координирани однос, чиме је постигнута структурна компатибилност и хармоничност цијеле реченице (в. Куљанин 2017: 39).

Анализирани примјери показали су да су у Андрићевом књижевном дјелу заступљена оба типа поредбеног поступка. Андрић одређени појам квалификује аналитичким формама базираним на основном граматикализованом моделу узлазног и силазног компаратива и суперлатива више/мане; највише/најмане + позитив придјева/прилога, у конкурентном односу са синтетичким, дакле, када су те форме међусобно супституентне. Синтетички облици у том случају подразумијевају комуникативну вриједност, а аналитички доприносе стилској вриједности, јер се тако, са аспекта говорног лица, аутора, наглашава, интензивира дата квалификација, постиже се структурна компатибилност и хармоничност реченице, а често аналитичке форме имају и еуфемистичку улогу. 


\section{Експресивни аналитички суперлатив}

Највећи број примјера из корпуса ипак представљају аналитичке конструкције које такође настају у зависности од контекста и намјере говорног лица и његовог става у вези са квалификацијом неког појма или процеса, а тим лексичким комбинацијама Андрић гради сложене експресивне форме са специфичним конституентима и њиховим семантичко-синтаксичким карактеристикама. Њима се одређеном појму приписују квалификације у највишем, суперлативно израженом степену, без експлицирања морфолошког суперлатива. Интерференција тих двају типова поредбеног поступка подразумијева или стилску (аналитичка форма), или комуникативну варијанту (синтетичка форма).

Иако су ове конструкције структурно различите, могу се издвојити неке формалне инваријантне карактеристике, али свим тим моделима аналитичке компарације заједнички је семантички еквивалент - придјевска/ прилошка синтетичка лексема с правим суперлативним значењем.

Прва конструкција аналитичког суперлатива коју ћемо анализирати реализује се према моделу: одрични замјенички прилог + нег. предикат + компаратив придјева/прилога (основни, инваријантни конституенти) и неексплицирана, подразумијевајућа (темпорална) одредба са значењем сада или досад, као нпр.:

(9) Никад нису двоје љубавника измијенили юежније додире руку (никад досад/никад као сада), ни дубље погледе, ни вище оних полумрачних ријечи које се разумију прије него се изговоре и остављају сласт једног миловања (= Двоје љубавника измијенили су најюежније додире руку, најдубтье погледе, и највище оних полумрачних ријечи ...) (ЕНЛ, 62). 
Право суперлативно значење у оваквој Андрићевој конструкцији остварује се уз присуство морфолошког компаратива, и то његовим одрицањем преко одричног прилога и одричног предиката. Експресивно-емоционални утисак који на читаоца оставља квалификовање реализовано према наведеном моделу, чија структура настаје Андрићевим избором лексема са одређеним морфолошким категоријама, много је јачи, а цијела конструкција много стилематичнија од синтетичке суперлативне форме. Аналитички суперлатив у овом примјеру служи као дио текста и као закључак и њиме Андрић слави љубав једног дана, када двоје љубавника измијене, синтетичким суперлативом исказано, најюежније додире руку и најдубље погледе, док је „љубав многих година”, како каже Андрић, „извржена промјенама, немилосрдним законима и бригама без броја”, а „љубав која траје мјесеце, пуна је изненађења и запрека, љубоморна и засићена, немирна и самовољна, мучена сумњама, обзирима и ситним мислима" (ЕНЛ, 62).

Према претходном моделу остварује се и сљедећи примјер:

(10) Природно је да у таквим приликама ничије тежње нису биле јасне ни разумљиве; ту се ничије заслуге нису могле право одмерити и ничије варке лако прозрети, ничије претензије потпуно одбити и ничије право поуздано утврдити и трајно поштовати. Никад бољих времена ни подеснијег тла за обману и самообману! (= најбола времена и најподесније тло за обману и самообману) (ГЂ, 140).

Овај примјер од претходног се разликује само по томе што је у њему редукован негирани глаголски облик. Осим тога, ову изузетно стилематичну конструкцију аналитичког суперлатива Андрић издваја у посебан екскламативни исказ као закључак претходног садржаја, а 
све то, кратко и ефектно, доприноси већој експресивној вриједности овако исказане суперлативне квалификације.

Сљедећим примјером представљена је суперлативна конструкција која се остварује према моделу: одрични замјенички прилог + интензибикаторска лексема тако + позитив придјева/прилога + негирани предикат, с тим што је за наведену конструкцију специфично неексплицирање позитива прилога много/јако.

(11) Нигдје се тако не осјећа дах пропадања и неког чистог, смиреног умирања као по авлијама наших старих кућа (= највише/најјаче се осјећа дах пропадања и неког чистог, смиреног умирања по авлијама наших старих кућа) (ЕНЛ, $52)$.

Оваквом синтаксичком конструкцијом исказује се право суперлативно значење, без присуства морфолошког компаратива или суперлатива. Подразумијевајуће својство, максимално испољено, везом одричног предиката и мјесног одричног замјеничког прилога, у суперлативном значењу приписује се само ентитету у функцији адвербијалне одредбе, а било којем другом одриче се заступљеност дате квалификације у тако високом степену. Специфичност овакве конструкције јесте експресивно изражавање максималног степена заступљености неке особине или својства, изразито емотивно обојено, јер је цијели исказ проткан носталгичним, тужним емоцијама и резигнацијом, тј. мирењем са судбином и оним што је неизбјежно, с пролазношћу живота. Осим тога, реченица с аналитичким суперлативом има и отварачку функцију, јер као једна општа констатација наговјештава суштину онога што ће тек бити разрађено и детаљније исказано, тј. најављује оно што слиједи, а то се на крају те цјелине и потврђује Андриће- 
вом реченицом: „Ја сам увијек (...) осјећао дах умирања око наше куће. И данас она стоји с лицем човјека који мирно слуша смртну осуду" (ЕНЛ, 52).

Аналитичке компарационе конструкције са суперлативним значењем реализују се и према моделу који чини: негирани предикат + компаратив придјева + од+генитив:

(12) (a) Hит има горег фратра од мене (= ја сам најгори фратар), нити поганијег Турчина од овог Осме (= Осмо је најпоганији Турчин) (Ж, 21); (б) Лепота је скупа, лудо скупа а ништавна и варљива ствар. Нема горег расипника ни веће опсене (од нее/од тьепоте) (=/она/льепота/ најгори је расипник и највећа опсена) (ГЋ, 17).

Перифрастичку форму са суперлативним значењем Андрић гради тако што везом негираног предиката и компаративне форме којом се квалификује одређени ентитет, из њега, тог ентитета, издваја појам исказан поредбеном генитивном формом и приписује му највећи степен дате квалификације. Други примјер (б) такође се реализује према наведеном моделу, међутим, овдје генитивна конструкција није експлицирана, али се подразумијева: од юее, од тьепоте, што је сасвим јасно из претходне реченице. Тако цијела аналитичка суперлативна конструкција има затварачку функцију, будући да служи за сумирање и закључивање, као констатација и категоричан Андрићев став, те редукована и издвојена у засебан исказ постаје изразито ефектна и експресивна.

Сљедећи примјери аналитичког суперлатива од претходних разликују се по томе што модел конституише nоmврдни предикат, компаративни облик и генитивна форма коју може представљати или општа замјеница (а) или појам са апсолутном заступљеношћу неке квалификације (б), која се у таквој синтаксичкој структури, у ствари, преноси на појам у функцији субјекта. На тај начин Андрић 
изразито експресивно одређени појам квалификује суперлативним или, тачније, „надсуперлативним” значењем.

(13) (а) Заборавио сам се и прекинуо за секунд ћутање, тек толико колико је требало да јој са пола речи кажем како сам неизмерно срећнији од свих људи на земљи (= најсрећнији) (Јелена, 262). Свашта се веровало и шапутало, али страх је био јачи од свега (= страх је био најјачи) (НДЋ, $53) ; . .$. али шта то вреди кад је свет такав да су у њему лаж и обмана моћнији од свега другог (= лаж и обмана су најмоћнији) (Ж, 193); Јер, има у једним људима безразложних мржња и зависти које су веће и јаче од свега... (= највеће $и$ најјаче).... (НДЋ, 59); (б) Она [штедња] одржава живот и трајност око нас, обогаћује нас стално и чини, тако рећи, вечним оно што имамо; она нас чува од трошка, губитака и нереда, од сиромашења, од беде која долази на крају а која је гора и ирна од смрти (= најгора и најирна) прави

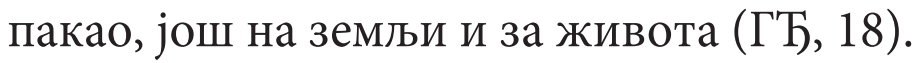

Овај модел има најпростију структуру међу сложеним лексичким комбинацијама са суперлативним значењем и веома је фреквентан. Конструкција с генитивном формом опште замјенице (факултативно се иза опште замјенице може употријебити и лексема други или остали у одговарајућем облику) много је ефектнија и стилематичнија од синтетичког, а и од основног граматикализованог перифрастичког суперлатива. Оваква перифрастичка конструкција, дакле, има право суперлативно значење и супституентна је синтетичким суперлативом наведеним у загради. Међутим, њоме се јаче изражава високи степен особине или својства јер се појам којем се приписује дата особина експлицитно издваја од свих других истоврсних појмова, чиме се наглашава суперлативна особина, али и већи емоционални значај за говорника.

Веома фреквентне аналитичке форме са суперлативним значењем представљају примјери у чији су модел 
укључени сљедећи елементи: одрична замјенииа + негирани предикат + компаративни придјев/прилог + него.

(14) Ништа није простије него (Најпростије је) изнети пред тог човека (...) своју праведну ствар и доћи до своје „правде”, ништа није природније него (најприродније је) да се царев амиџа заузме за Симанову ствар (Јелена, 58); Ништа није теже ни страшније него (Најтеже и најстрашније је) гледати свет око себе очима бивше лепотице (Јелена 240/241).

Перифрастички суперлатив остварен према овом моделу такође изражава максимални степен особине, еквивалентан значењу које исказује и синтетички суперлатив наведен у загради, што очито показује могућност њихове супституције, али, као и остале сложене синтаксичке конструкције са суперлативним значењем, моделски овдје представљене, на много упечатљивији и експресивнији начин.

Ако се умјесто одричне замјенице као у претходном моделу, употријеби одрични замјенички прилог (никад), a уз негирани предикат додамо количински прилог са интензификаторском функцијом толико, добије се експресивни аналитички суперлатив као у првој клаузи сљедећег примјера. Друга клауза садржи аналитички суперлатив који се остварује према претходном моделу, али се уз него додаје одредба времена:

(15) А никад није тих чистина било толико (= сада је највище тих чистина) и никад се није тим путевима брже и лакше напредовало него сада (= сада се најбрже и најлакше напредује тим путевима) (ГЂ, 104).

Аналитички суперлатив може се исказати и у форми реторичког питања, што додатно доприноси експресивности таквог модела будући да је специфичност рето- 
ричког питања одступање од уобичајене комуникативне употребе, јер се упитном формом и упитно-екскламативном интонацијом у ствари исказује тврдња и тиме постиже изузетан стилистички ефекат. Такав је нпр. Андрићев исказ:

(16) Нашем Реду треба један грешник, ако ни рад чега а оно ради примјера, а гдје ћете наћи бољег од мене? (= нигдје нећете наћи бољег од мене = ја сам најбољи $)(Ж, 84)$.

Да бисмо открили Андрићево перифрастичко суперлативно квалификовање у овом примјеру, потребно је извршити двоструку трансформацију: прво се реконструише граматичко-комуникативни еквивалент реторичком питању (нигдје нећете наћи бољег од мене), а затим и функционално-семантички еквивалент перифрастичком суперлативу (ја сам најбољи). Изражавање суперлативног значења на овај начин много је емоционалније и експресивније јер се испољава пишчева доживљеност и оживљавање читаоцу одређене ситуације.

Анализираним примјерима перифрастичког суперлатива нису обухваћени сви модели и њихове варијанте у издвојеном корпусу, а осим њих постоје и други, више оказионални, јер се наведени донекле могу сматрати граматикализованим моделима. Њихова основна карактеристика јесте сложена структура, али монолитно значење или, друкчије речено, формално-граматички и семантички план обједињени су заједничким категоријалним значењем степена. Анализиране конструкције и модели показују да категоријално значење суперлативности може бити исказано и изван морфолошког система, тј. да постоје лексичко-граматичке конструкције без присуства суперлативног облика у њиховом саставу. Анализа Андрићевих примјера јасно је показала да су синтетичке и аналитичке форме за изражавање суперлативног зна- 
чења у конкурентском односу и да се аутор може опредијелити и за једну и за другу, али су аналитичке много стилематичније и експресивније и аутору дају велике могућности за специфично, субјективно квалификовање одређене особине или својства, и такав поредбени поступак подразумијева стилску варијанту, док морфолошке, синтетичке форме подразумијевају само комуникативну варијанту.

Ексцерпирани примјери структурисани према наведеним моделима и њиховим варијантама показали су различите могућности изражавања суперлативног значења, међутим, да ли ће богатство српског језика и све оно што је његовом кориснику на располагању бити у пуној мјери и на најбољи начин искориштено зависи од самог говорног лица, тј. аутора, а Андрићева ингениозност у томе је неспорна и изузетна.

\section{Закључак}

Проведена анализа примјера синтетичке и аналитичке компарације показала је да су у Андрићевом књижевном дјелу заступљена оба типа поредбеног поступка у складу с аспектом да је синтетичка примарна за узлазну, а аналитичка за силазну компарацију. Интерференција двају типова поредбеног поступка подразумијева или стилску или комуникативну варијанту. Стилска варијанта долази до изражаја када Андрић аналитичким формама исказује компаративно или суперлативно значење у оквиру конкурентне компарације, док синтетички облици у том случају подразумијевају комуникативну вриједност. Како су примјери показали, Андрић одређени појам квалификује аналитичким формама базираним на основном граматикализованом моделу узлазног и силазног компаратива и суперлатива вище/ 
мане; највише/најмағе + позитив придјева/прилога, у конкурентном односу са синтетичким, дакле, када су те форме међусобно супституентне, што доприноси стилској вриједности, јер се тако, са аспекта говорног лица, аутора, наглашава, интензивира дата квалификација, постиже се структурна компатибилност и хармоничност реченице, а често аналитичке форме имају и еуфемистичку улогу.

Изразиту експресивност и стилску вриједност имају лексичке комбинације са специфичним конституентима и њиховим семантичко-синтаксичким карактеристикама, којима Андрић одређеном појму приписује квалификације у највишем, суперлативно израженом степену, без експлицирања морфолошког суперлатива, којим је перифрастичка конструкција потпуно замјењива, али у том случају преовладава комуникативна, а не стилска варијанта. У овоме раду су анализирани различити модели аналитичког суперлатива, донекле граматикализовани (наравно не сви који су ексцерпирани из Андрићевог дјела), који аутору отварају велике могућности за специфично, субјективно квалификовање одређене особине или својства, тако да се и овим конструкцијама потврђује Андрићева изванредна минуциозност и ингениозност. То се запажа и у великом броју оказионалних аналитичких суперлативних конструкција, али због ограниченог простора, њих овом приликом није ни могуће анализирати.

\section{Извори}

ГЂ): Ivo Andrić, Gospođica, Sabrana djela Ive Andrića, knjiga treća, Udruženi izdavači, Sarajevo, 1981.

ЕНЛ: Ivo Andrić, Exponto, nemiri, lirika, Sabrana djela Ive Andrića, knjiga jedanaesta, Udruženi izdavači, Sarajevo, 1981. 
Ж: Ivo Andrić, Žeđ, Sabrana djela Ive Andrića, knjiga šesta, Udruženi izdavači, Sarajevo, 1981.

Јелена: Ivo Andrić, Jelena, žena koje nema, Sabrana djela Ive Andrića, knjiga sedma, Udruženi izdavači, Sarajevo, 1981.

НДЋ: Ivo Andrić, Na Drini ćuprija, Istočno Sarajevo: Zavod za udžbenike i nastavna sredstva, 2011.

Омерпаша: Ivo Andrić, Omerpaša Latas, Sabrana djela Ive Andrića, Udruženi izdavači, Sarajevo, 1982.

\section{Литература}

Ковачевић 2003: Милош Ковачевић, Граматичке и стилистичке теме, Бањалука: Књижевна задруга.

Куљанин 2017: Сања Куљанин, Компарација кроз тексику и семантику, Београд: Јасен.

Правопис српскога језика 2010: Митар Пешикан, Јован Јерковић, Мато Пижурица, Правопис српскога језика, измењено и допуњено издање, Нови Сад: Матица српска.

Рајић 2016: Јелена Рајић, Увод у прагматику, Београд: Филолошки факултет Универзитет у Београду.

Sanja M. Kuljanin

\section{KONKURRENZFÄHIGKEIT DER SYNTHETISCHEN UND ANALYTISCHEN KOMPARATION IN ANDRIĆS WERK}

Die synthetische und analytische Komparation unterscheidet sich grundlegend in dem Aspekt, dass die Steigerung und Minderung betrifft. Für die aufsteigende,primär die synthetische und für mindernde, die analytische Komparation. Im Referat wurde Andrićs literarischer Text durch die Interferenz von zwei Typen von Vergleichsverfahren analysiert, welche die stilistische oder kommunikative Variante voraussetzt. 
Andrić qualifiziert einen bestimmten Begriff mit analytischen Formen basierend auf dem Primärmodell grammatikalisierend auf- und absteigenden Komparativs- und Superlativs mehr/weniger; am meisten/am wenigsten + das Positiv des Adjektivs/Adverbs, im Konkurrenzverhältnis mit dem Syntetischen, demzufolge, wenn diese Formen untereinander Substituent sind, was zu dem stilistischen Wert beiträgt, während synthetische Formen in diesem Fall einen kommunikativen Wert implizieren.

Eine ausgeprägte Ausdruckskraft und stilistischen Wert haben verschiedene analytische Modelle der Superlative, einigermaßen grammatikalisier, die dem Autor große Möglichkeiten für spezifische, subjektive Qualifizierungen bestimmter Merkmale oder Eigenschaften öffnen, so dass insbesondere mit diese Strukturen Andrićs außerordentliches Einfallsreichtum und besonderes stilvolles Verfahren bestätigt wird.

Schlüsselwörter: Komparation, synthetisch, analytisch, Stiegerung, Minderung, Expressivität. 